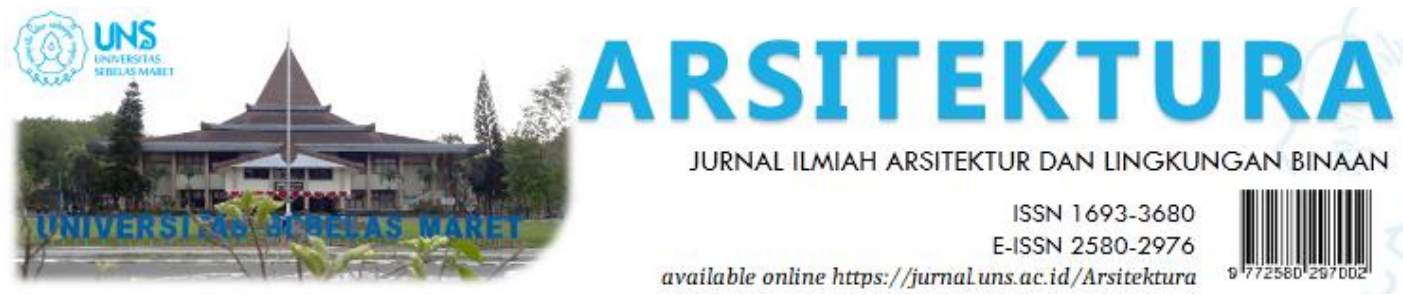

Volume 18 Issue 1 April 2020, pages:13-26

\title{
Penerapan Ekowisata Pada Perancangan Hotel Resort Bintang Tiga di Pacet
}

\section{Ecotourism Application At Three Star Resort Hotel Design In Pacet}

\author{
Vicky Al'yah $^{1 *}$, Desrina Ratriningsih ${ }^{2}$ \\ Program Studi Arsitektur, Fakultas Sains dan Teknologi Universitas Teknologi Yogyakarta ${ }^{\text {* }}$ \\ vicky.alyah@student.uty.ac.id \\ Program Studi Arsitektur, Fakultas Sains dan Teknologi Universitas Teknologi Yogyakarta² \\ desrina@uty.ac.id
}

DOI: https://doi.org/10.20961/arst.v18i1.31068

Received: June 23, 2019 Revised: January 26,2020 Accepted: February 12,2020 Available online: April 30, 2020

\begin{abstract}
Pacet is one of the natural attractions in Mojokerto Regency, East Java. According to the Mojokerto Regency Spatial Plan for 2012-2032, the area of Pacet is a prioritized area for tourism development. Most of tourist areas in Mojokerto, especially in Pacet, have an increase of 30\%-70\% of visitors since 2015, one of which is Padusan Pacet Tourism Wana. However, it is unfortunate that the increasing number of tourists is not followed by the development of tourist accommodation. Based on the natural potential of Pacet with a cool and pollution-free atmosphere, the application of the Ecotourism concept to Resort Hotel buildings is expected to benefit the surrounding environment in Pacet. The application of Ecotourism to the design of Resort Hotels will be focused on the natural potential of Pacet (Natural Area Focus). In addition, in the future, there will also be land conservation and plants to preserve the natural ecosystem of Padusan (Contribution To Conservation). This concept incorporates local cultural elements of Pacet (Cultural Respect) in Mojokerto District to attract tourists to stay at Resort Hotels in Pacet.
\end{abstract}

Keywords: Ecotourism and Resort Hotel

\section{PENDAHULUAN}

Wisata alam saat ini telah menjadi trend beberapa tahun terakhir. Pada beberapa daerah pembangunan perkembangan wisata alam saat ini sudah mulai di tingkatkan guna meningkatkan perkembangan ekonomi daerah. Pacet merupakan salah satu kawasan yang berada di Kabupaten Mojokerto Provinsi Jawa Timur yang memiliki panorama alam yang bagus dengan tingkat polusi yang rendah. Sesuai dengan Rencana Tata Ruang Wilayah kawasan Pacet paragraf ketujuh tentang peruntukan pariwisata alam pasal 47 ayat 6 bagian b no 1 berbunyi "Kawasan prioritas perkembangan wisata alam di pusatkan di kecamatan Pacet'(Mojokerto n.d.), dengan adanya RTRW tersebut dapat disimpulkan bahwa kawasan Pacet memang merupakan kawasan yang di peruntukkan untuk wisata alam. Pada beberapa tahun terakhir peningkatan wisata yang berdestinasi di Pacet mengalami peningkatan sebesar $30 \%-70 \%$ sejak tahun 
2015 salah satunya di Wana Wisata Padusan Pacet. Jumlah total pengunjung obyek wisata air panas Padusan mencapai 175,142 pengunjung di tahun 2013 menjadi 214,540 pengunjung di tahun 2015. Namun sangat disayangkan dari peningkatan jumlah pengunjung tersebut ternyata banyak wisatawan yang memilih untuk menginap di daerah lain yang dekat dengan kawasan Pacet dikarenakan jumlah akomodasi penginapan di Pacet tidak mampu untuk menampung jumlah pengunjung yang datang atau yang berdestinasi di Pacet. Menurut hasil survey penulis pada tahun 2018 jumlah akomodasi penginapan di pacet sekitar 169 kamar dari total seluruh penginapan yang ada di Pacet. Dari total akomodasi penginapan yang ada di Pacet dinilai kurang untuk mengakomodasi wisatawan yang berdestinasi di Pacet.

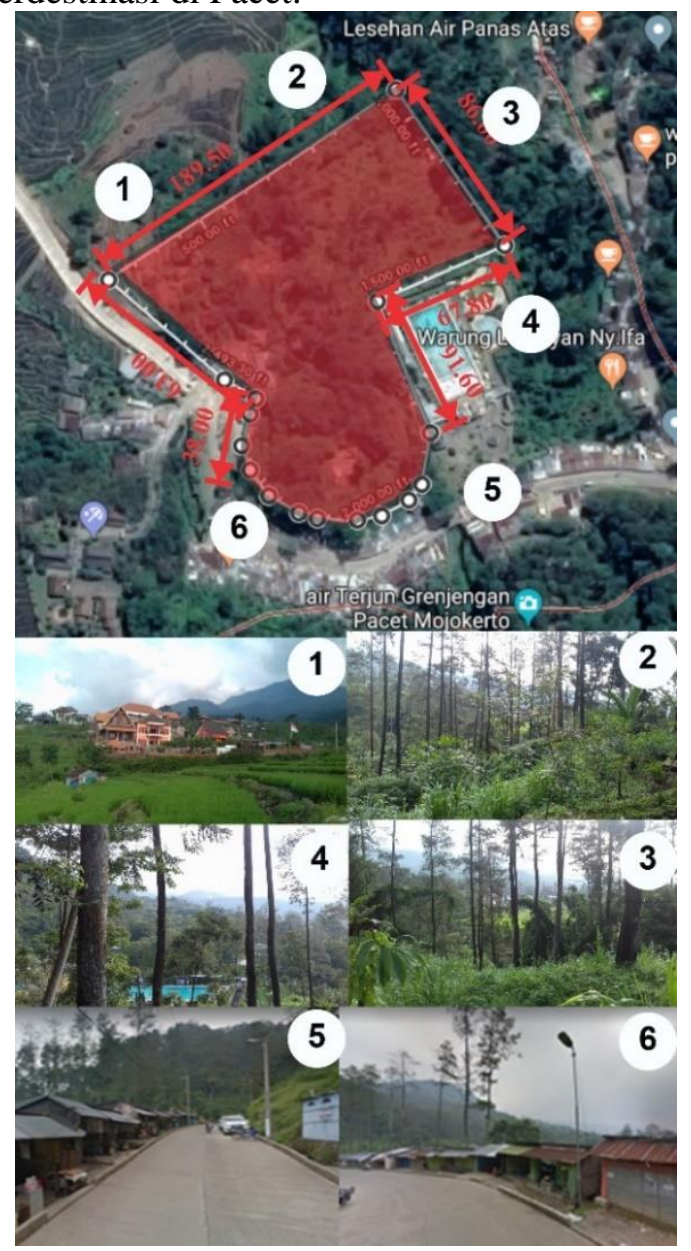

Gambar 1. Peta Eksisting Site

\subsection{Ekowisata}

Menurut The International Ecotourism Society, 2015(Society 2015) Ecotourist atau Ekowisata adalah perjalanan yang bertanggung jawab ke daerah alami yang melestarikan lingkungan, menopang kesejahteraan masyarakat setempat, melibatkan interpretasi serta pendidikan lingkungan hidup. Ekowisata kini telah berkembang sesuai dengan perkembangan popularitas wisata alam yang merujuk kepada pariwisata masal tradisional dengan gabungan gagasan tentang konservasi alam. Ekowisata sendiri juga dapat masuk dalam perkembangan ekonomi daerah. Menurut Tisnawati, et al., 2019(Kampung et al. 2019) "Penghasilan Ekowisata adalah dari jasa-jasa wisata untuk turis, biaya pemandu, homestay, menjual kerajinan, dll." Dari teori tersebut dapat disimpulkan bahwa ekowisata tidak hanya merujuk pada lingkungan dan konservasi alam namun juga mencakup keseluruhan termasuk ekonomi dan perkembangan lingkungan sosial masyarakat sekitar. Sesuai dengan Peraturan Menteri tentang pedoman pengembangan ekowisata di daerah(NEGERI 2009) “ Pengembangan ekowisata wajib memberdayakan masyarakat setempat." Sektor akomodasi fasilitas yang ada dapat mempengaruhi perkembangan wisata yang ada di suatu daerah. Ekowisata sendiri memiliki 8 prinsip menurut Arachchi, et al., 2015(Shukri and Yajid 2015) yaitu:

a. Konsentrasi dalam memberi kesempatan kepada pengunjung secara individu dan langsung pengalaman alam (Natural Area Focus)

b. Menawarkan kesempatan untuk mengalami alam dengan cara yang mengarah pada pemahaman rasa hormat dan kepuasan yang lebih baik (Interpretasi)

c. Berdiri untuk praktik terbaik untuk wisata ramah lingkungan (Environmental Sustainability Practice)

d. Berkontribusi langsung dengan konservasi kawasan alami (Contribution to Conservation)

e. Menawarkan pemanfaatan potensi yang dapat membantu peningkatan ekonomi sekitar dan dapat membantu kesejahteraan masyarakat setempat (Benefit Local Communities) 
f. Peka untuk memahami dan melibatkan budaya yang ada di daerah tersebut (Cultural Respect)

g. Setiap saat memenuhi kebutuhan konsumen (Customer Expectation) dan

h. Didorong dengan tulus dan jujur sehingga harapan praktis terbentuk (Responsible Marketing)

Dengan potensi panorama alam Pacet yang sejuk dan bebas polusi penerapan Ekowisata pada bangunan Hotel Resort di Pacet di harapkan dapat memberikan benefit pada lingkungan sekitar yang ada di Pacet. Dari 8 prinsip di atas ada 3 prinsip yang akan di terapkan pada bangunan Hotel Resort di antaranya sebagai berikut:

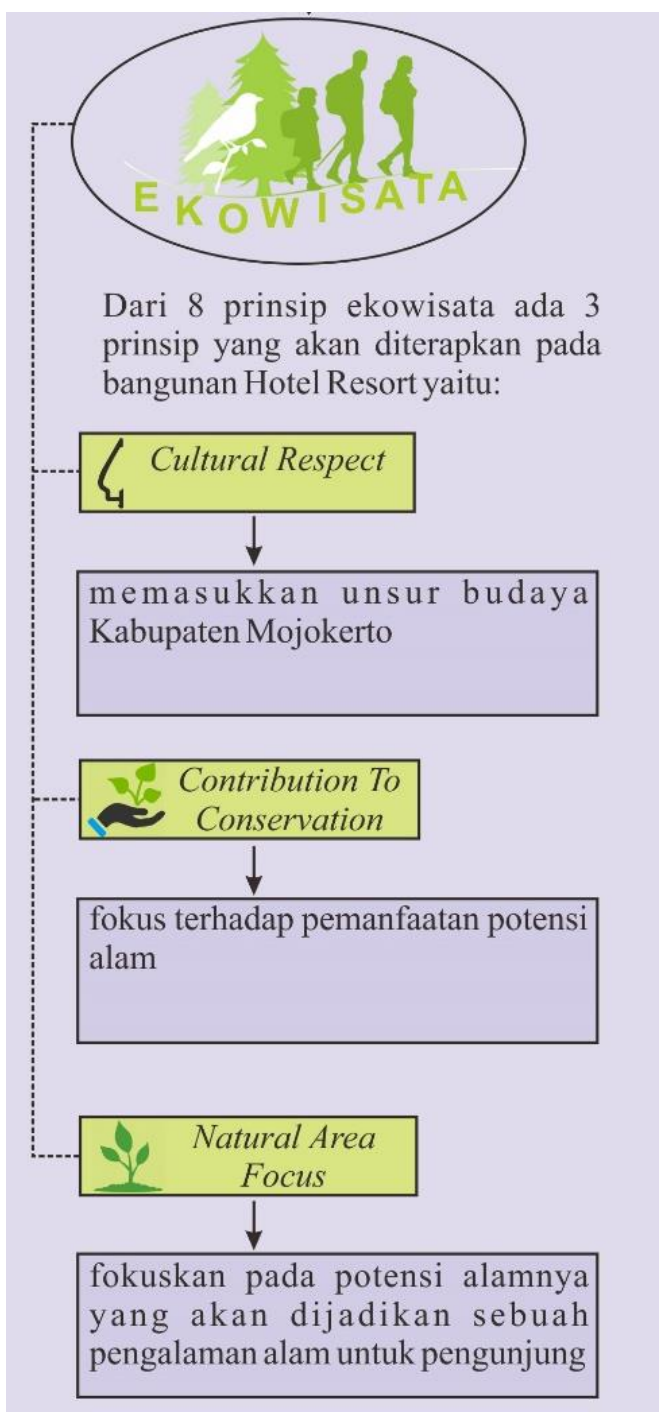

Gambar 2. Penerapan Ekowisata

\subsection{Hotel Resort}

Hotel resort merupakan Hotel yang terletak di kawasan wisata. Menurut Fifi, et al., 2012(Fifi Ambarwati, Agung Kumoro W. 2012) Hotel Resort berfungsi sebagai tempat menginap dan juga sebagai sarana rekreasi karena lokasinya berada di kawasan wisata. Beberapa Hotel Resort tidak hanya menyediakan penginapan saja melainkan juga menyediakan beberapa fasilitas yang dapat di nikmati wisatawan yang menginap atau wisatawan yang hanya berniat untuk menikmati fasilitas yang ada di hotel resort seperti fasilitas SPA, Tempat Olahraga, Resto, dll. Menurut Marlina(Marlina 2008) Hotel Resort merupakan Hotel yang di bangun di kawasan tempat wisata yang di fungsikan untuk mengakomodasi wisatawan yang berkunjung. Berikut merupakan beberapa klasifikasi Hotel Resort berdasarkan lokasi dan fasilitasnya.

a. Beach Resort Hotel

Resort ini terletak di daerah pantai, mengutamakan potensi alam dan laut sebagai daya tariknya.

b. Marina Resort Hotel

Resort ini terletak di kawasan marina (pelabuhan laut). Oleh karena terletak di kawasan marina, rancangan resort ini memanfaatkan potensi utama kawasan tersebut sebagai kawasan perairan.

c. Mountain Resort Hotel

Resort ini terletak di daerah pegunungan. Pemandangan daerah pegunungan yang indah merupakan kekuatan lokasi yang dimanfaatkan sebagai ciri rancangan resort ini.

d. Health Resort and Spas

Resort hotel ini dibangun di daerah-daerah dengan potensi alam yang dapat dimanfaatkan sebagai sarana penyehatan, misalnya melalui aktivitas spa. Rancangan resort semacam ini dilengkapi dengan fasilitas untuk pemulihan kesegaran jasmani, rohani, maupun mental serta kegiatan yang berhubungan dengan kebugaran.

e. Rural Resort and Country Hotels

Resort hotel yang dibangun di daerah pedesaan jauh dari area bisnis dan keramaian. 


\section{f. Themed Resorts}

Resort jenis ini dirancang dengan tema tertentu, menawarkan atraksi yang spesial sebagai daya tariknya.

g. Condiminium, Time Share, and Residental Development

Resort ini mempunyai strategi pemasaran yang menari. Sebagian dari kamar resort ini ditawarkan untuk disewa selama periode waktu yang telah ditentukan dalam kontrak, biasanya dalam jangka panjang.

h. All-suites hotels

Resort jenis ini tergolong resort mewah yang semua kamar disewakan dalam hotel tersebut tergolong ke dalam kelas suite.

$i$. Sight-seeing Resort Hotel

Resort hotel ini terletak di daerah yang mempunyai potensi khusus atau tempattempat menarik seperti pusat perbelanjaan, kawasan bersejarah, tempat hiburan, dan sebagainya.

Dari klasifikasi Hotel Resort di atas dipilih Mountain Resort Hotel, dikarenakan lokasi Pacet berada di daerah pegunungan yang memiliki pemandangan atau view yang indah dan dapat dijadikan kekuatan daya tarik dari daerah Pacet yang dimanfaatkan sebagai ciri Hotel Resort di Pacet

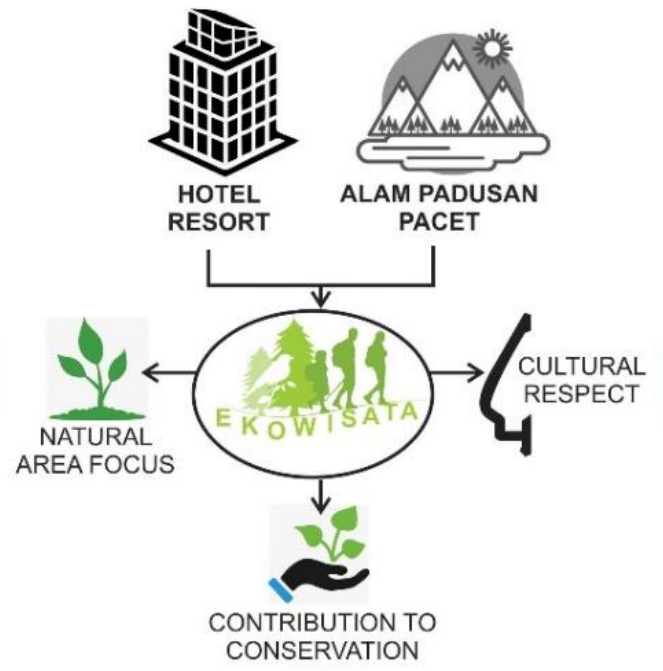

Gambar 3. Konsep Pada Hotel Resort

Hotel dapat disebut resort apabila dilengkapi dengan berbagai fasilitas, amenitas dan layanan lainnya, sehingga semua kebutuhan wisatawan dapat dipenuhi di tempat tersebut, oleh karena itu dalam aspek layanan sering disebut dengan one stop services. (Resort and Berkelanjutan 2014)

Keberadaan resort sendiri tidak hanya memenuhi kebutuhan wisatawan dengan berbagai layanan dan atraksi wisata, melainkan juga harus berfungsi menjaga lingkungan dan budaya masyarakat yang ada di sekitarnya(Resort and Berkelanjutan 2014).

\section{METODE}

Metode perancangan Hotel Resort Bintang 3 Di Pacet merupakan penjelasan dari proses perancangan yang disertai dengan teori-teori dan data-data yang didapat dari studi literatur maupun studi lapangan, sehingga dari proses tersebut dapat memberikan suatu gambaran yang bersifat mendukung objek pada perancangan. Kerangka kajian yang digunakan dalam proses perancangan Hotel Resort di Pacet Kabupaten Mojokerto ini secara umum. Tahapan kajian yang digunakan dalam perancangan Hotel Resort di Pacet Kabupaten Mojokerto:

1. Pencarian ide/ gagasan untuk kebutuhan akomodasi penginapan di Pacet Kabupaten Mojokerto yang kurang memadai sehingga dipilihlah Hotel Resort Bintang 3 untuk memfasilitasi wisatawan

2. Ide perancangan diperoleh dari pemikiran tentang bangunan yang dapat berfungsi sebagai fasilitas wisatawan namun dengan memanfaatkan potensi alam sekitar Pacet sebagai daya tari wisatawan. Sehingga, terciptalah sebuah ide tentang Penerapan Ekowisata Pada Perancangan Hotel Resort Bintang 3 Di Pacet.

3. Pematangan ide perancangan didapat dari data informasi tentang Arsitekturan maupun Non Arsitektural dari berbagai jurnal, literature, dan media yang difungsikan sebagai pembanding

4. Proses pengembangan ide/gagasan kemudian dituangkan dalam bentuk Konsep

Dari tahapan-tahapan tersebut menghasilkan sebuah penerapan konsep pada desain berupa bentuk massa, dan prespektif visualisasi pada desain. 


\section{HASIL DAN PEMBAHASAN}

\subsection{Lokasi Tapak}

Pada kondisi lokasi sekitar site sangat dekat dengan kawasan Wana Wisata Padusan. Memiliki view perbukitan yang bagus dan didukung dengan akses ke lokasi site sangat mudah dan sejalur dengan kawasan Wana wisata Padusan, sehingga akses pengunjung ke tempat wisata juga cukup dekat. Kondisi alam di sekitar site sangat bagus sehingga dapat dimanfaatkan juga sebagai konservasi alam dan warga disekitar juga merupakan pemilik kios cindera mata yang dapat dijadikan sebagai fasilitas sekitar site dan juga dapat membantu peningkatan pariwisata dan ekonomi kawasan. Luas lahan site sendiri sekitar $21.000 \mathrm{~m}^{2}$ atau 2,1ha dan berkontur dengan batas sebagai berikut :

- Utara : Lahan Kosong

- Selatan : Jalan Padusan Pacet

- Timur : Wana Wisata Padusan

- Barat : Jalan Padusan Pacet

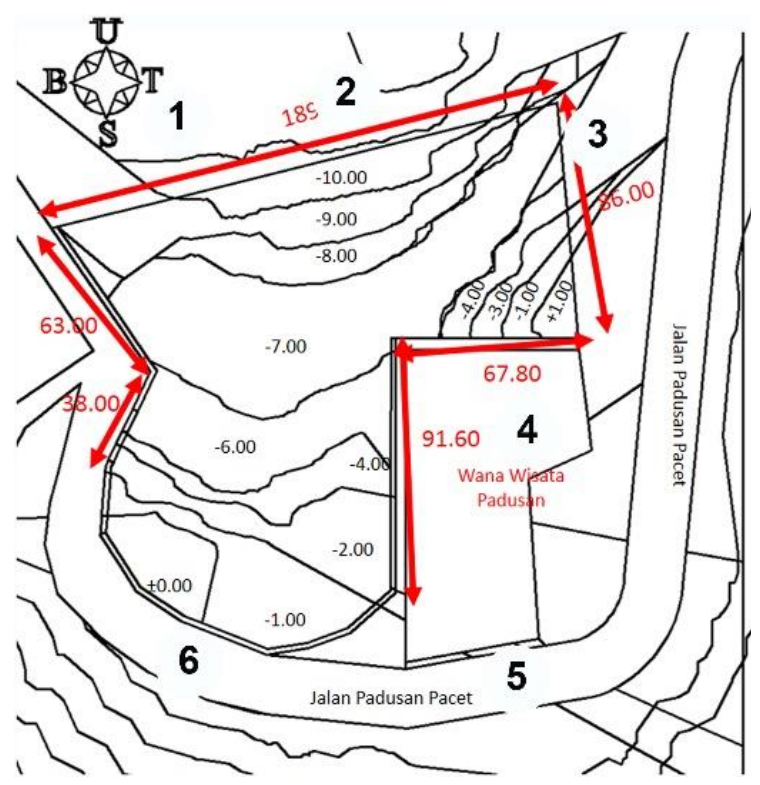

Gambar 4. Eksisting dan Kondisi Kontur

Lokasi site memiliki jalan dengan lebar Jalan Padusan $\pm 9 \mathrm{~m}$ pada sisi Barat Laut dan $\pm 12 \mathrm{~m}$ dengan tipe jalan aspal. Menurut PERDA Kabupaten Mojokerto pemanfaatan lahan pada kawasan perencanaan Hotel
Resort di kawasan Pacet Mojokerto adalah sebagai berikut (Sumber : RTRW Kab. Mojokerto 2012-2032):
- $\mathrm{KDB}$
$: 80 \%$
- $\mathrm{KLB}$
$: 6$
- $\mathrm{KDH}$
$: 10 \%$

\subsection{Penerapan Ekowisata}

Dari data eksisting pada site hanya 3 prinsip Ekowisata yang dapat di aplikasikan pada desain Hotel Resort nantinya di antaranya:

\section{a. Natural Area Focus}

Konsentrasi dalam memberi kesempatan kepada pengunjung secara individu dan langsung pengalaman alam.

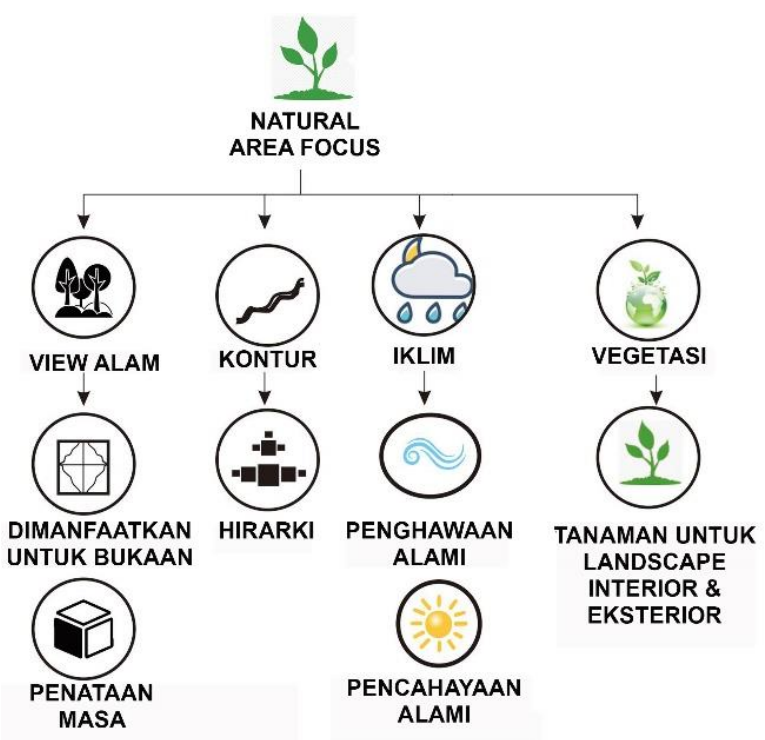

Gambar 5. Penerapan Ekowisata Natural Area Focus

- Vegetasi

Memberikan tanaman tambahan pada area landscape indoor maupun outdor yang difungsikan sebagai view dalam site untuk pengunjung memberikan kesan alami dan membuat sirkulasi udara yang ada disekitar site sejuk karena terdapat hutan pinus yang tinggi.

- View Alam

Area bukaan penginapan akan diberikan pada sisi utara yang memiliki view perbukitan dan sawah terasering sehingga pengunjung yang menginap dapat 
menikmati view secara maksimal. Dari potensi tersebut maka area penginapan nantinya hanya akan di fokuskan di bagian utara guna memanfaatkan potensi view yang ada di Padusan.

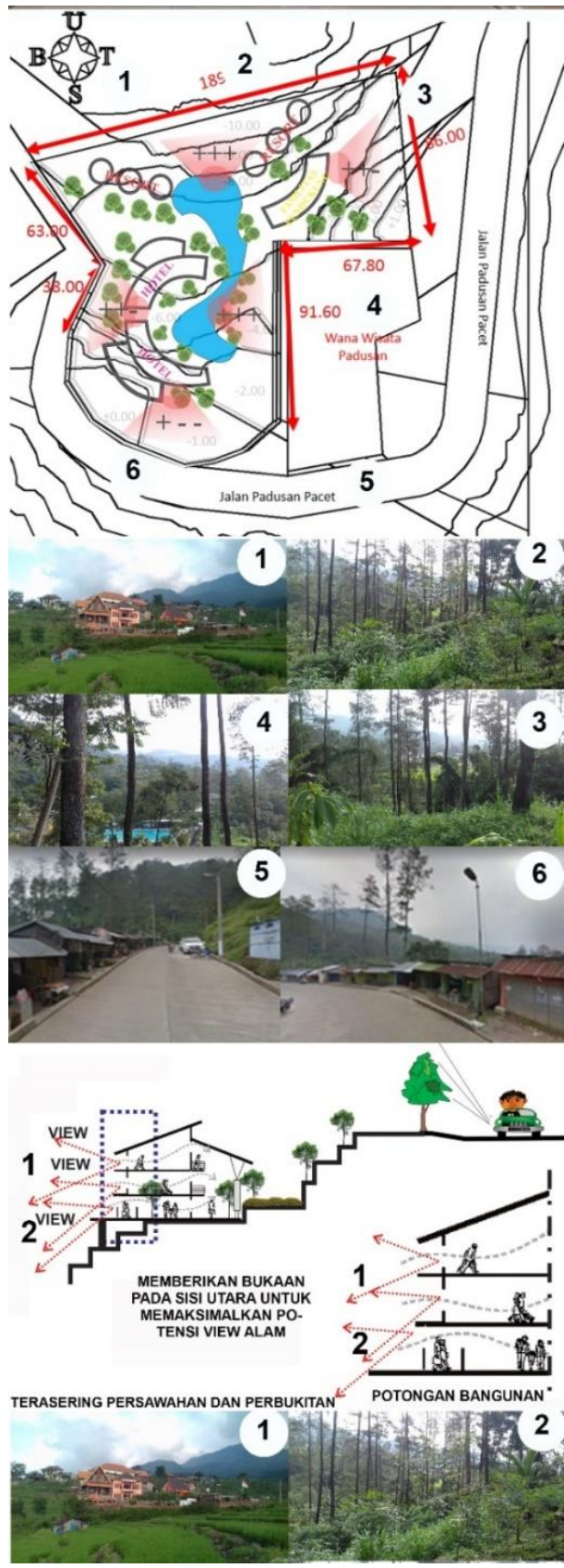

Gambar 6. Analisis Potensi View

- Iklim

Pemanfaatan arah matahari dan arah angin untuk menentukan bukaan sehingga pencahayaan dan penghawan dapat masuk kedalam ruangan dan dapat mengurangi pencahayaan dan penghawan buatan pada pagi dan siang hari

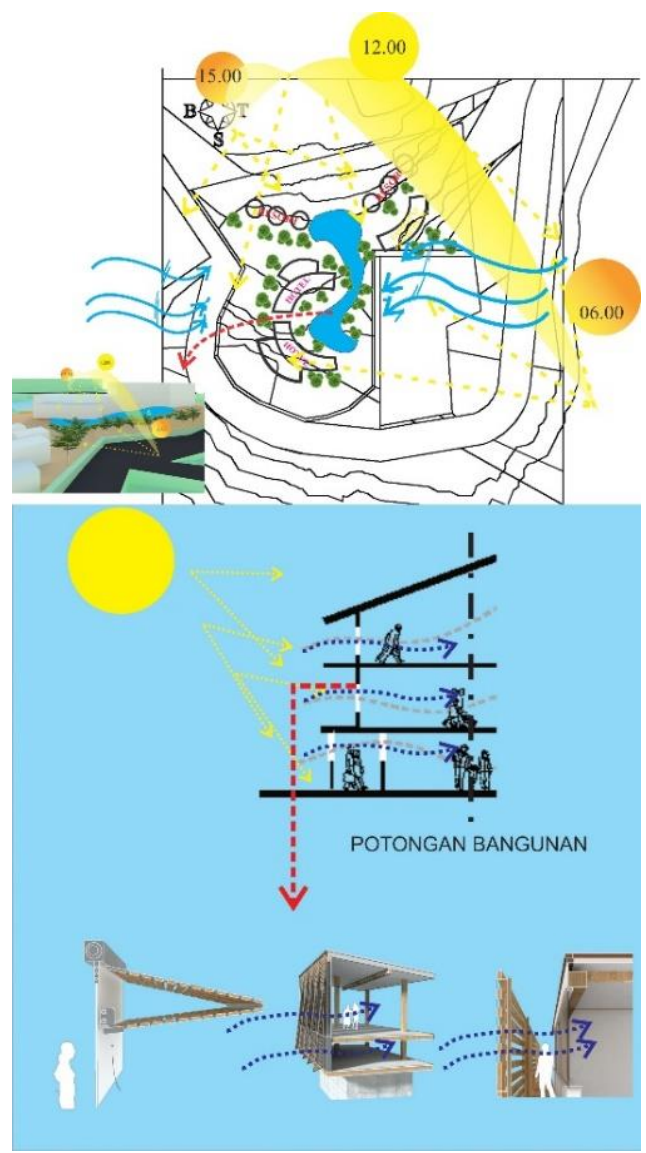

Gambar 7. Analisis Iklim Sekitar Site

- Kondisi Topografi

Pemanfaatan kontur tanah dalam penataan masa bangunan yang dapat membuat hirarki pada bangunan dengan membuat atau menata ruang secara split level untuk mengurangi cut and fill pada site sehingga ekosistem yang ada didalam site tidak rusak. Pemisahan masa nanti akan disesuaikan dengan kontur seperti pada bagian tengah site kondisi kontur tanah cenderung datar maka dari itu nantinya pada bagian tengah akan diletakkan masa hotel yang dibawahnya dilengkapi dengan akses sirkulasi untuk wisatawan supaya dapat santai pada saat berjalan menikmati suasana alam saat menuju ke beberapa masa yang lain atau menuju ke penginapan. Selain itu karena kondisi tanah yang berkontur nanti akan dibuatkan Ramp sebagai sirkulasi antar masa 


\section{b. Cultural Respect}

Peka untuk memahami dan melibatkan budaya yang ada di daerah tersebut dengan memasukkan unsur - unsur Majapahit dimana Kecamatan pacet berada di Kabupaten Mojokerto yang terkenal sangat kental dengan budaya Majapahit ada beberapa aspek non fisik dan fisik dari budaya majapahit yang nantinya akan diterapkan pada design Hotel Resort

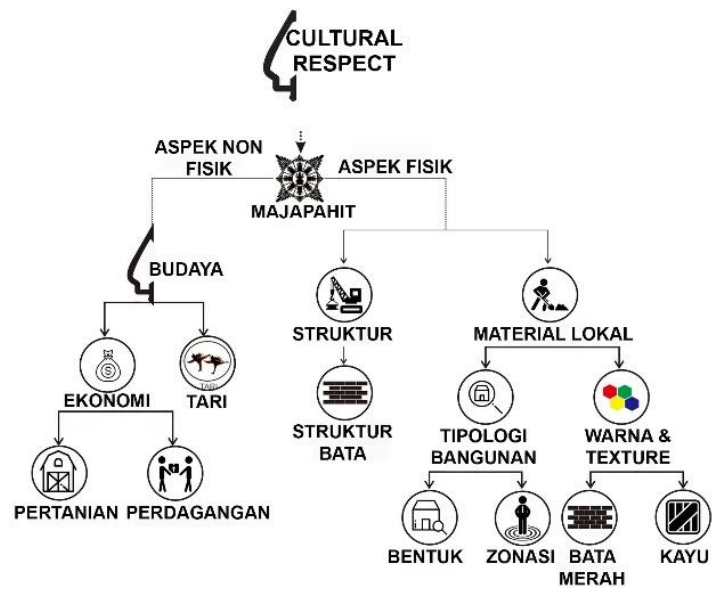

Gambar 8. Penerapan Cultural Respect

- Aspek Non Fisik

Pada aspek budaya nantinya akan memasukkan unsur budaya seperti Tari, Agama, dan Ekonomi. Nantinya akan di berikan wadah untuk menampung kegiatan tersebut dalam bentuk memberikan ruang untuk mewadahi budaya tersebut seperti memberikan ruang serbaguna sebagai ruang untuk mengadakan pertunjukan.

- Aspek Fisik

Pada aspek fisik nantinya akan mengaplikasikan material lokal seperti batu-bata dan kayu yang memang merupakan material dasar dari bangunan Majapahit dan mentransformasikan bentuk bangunan dari tipologi bangunan Majapahit dan gerbang dari Majapahit yang merupakan suatu ciri khas dari kota Mojokerto itu sendiri.

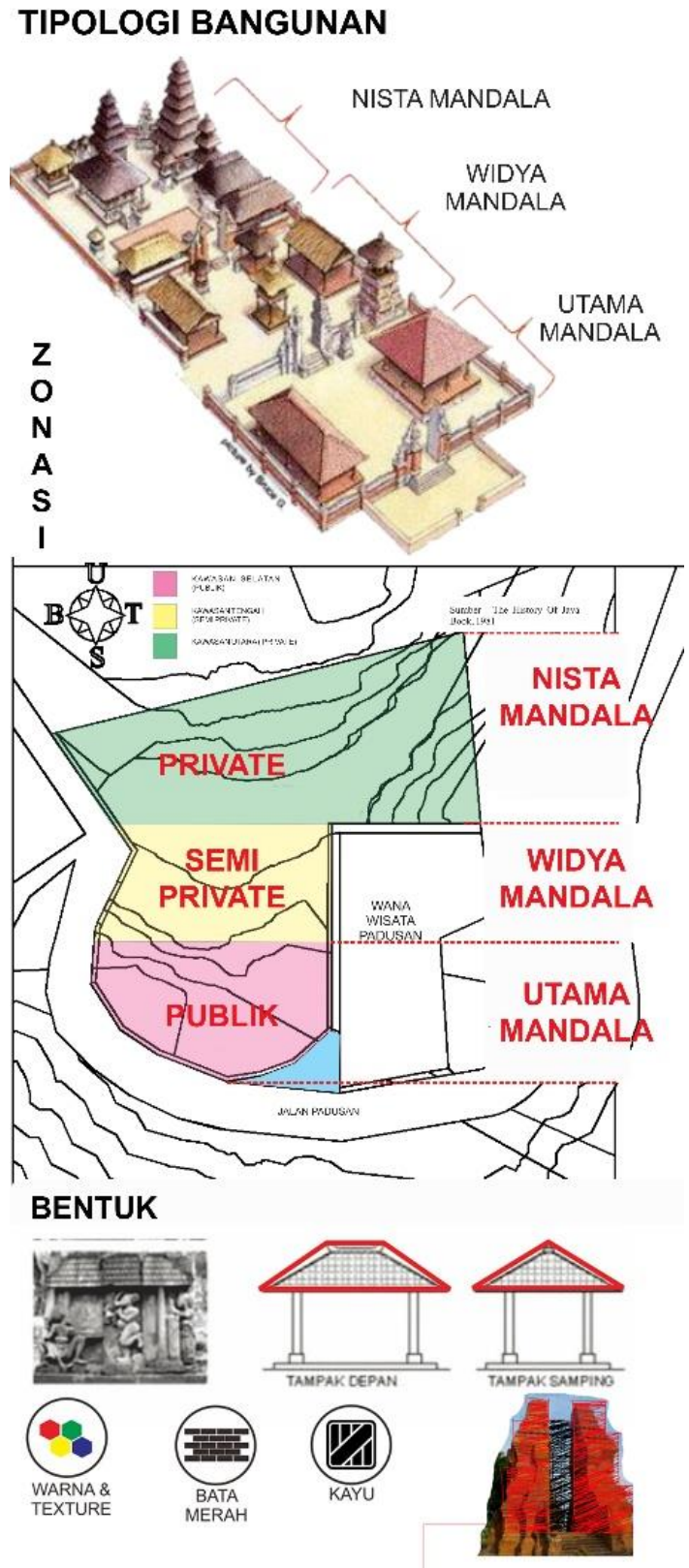

Gambar 9. Aspek Fisik

\section{c. Contribution To Consevation}

Mempertahankan eksisting sekitar site dan mengurangi kerusakan alam yang ada disekitar site. Memanfaatkan kondisi eksisting sekitar seperti menggunakan sumber air panas sebagai fasilitas pendukung yang ada di Hotel Resort dan memanfaatkan vegetasi eksisting untuk mempertahankan daya dukung tanah yang ada disekitar site. 


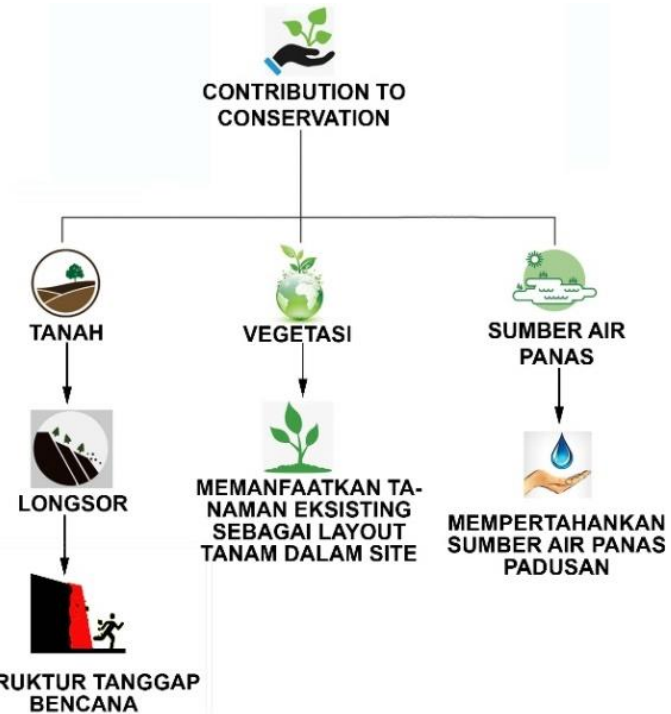

Gambar 10. Penerapan Contribution To Conservstion

- Vegetasi

Mempertahankan vegetasi eksisting untuk mempertahankan kondisi tanah dan menambahkan beberapa vegetasi yang dapat memperkuat daya dukung tanah dan menambah view dalam site untuk pengunjung.

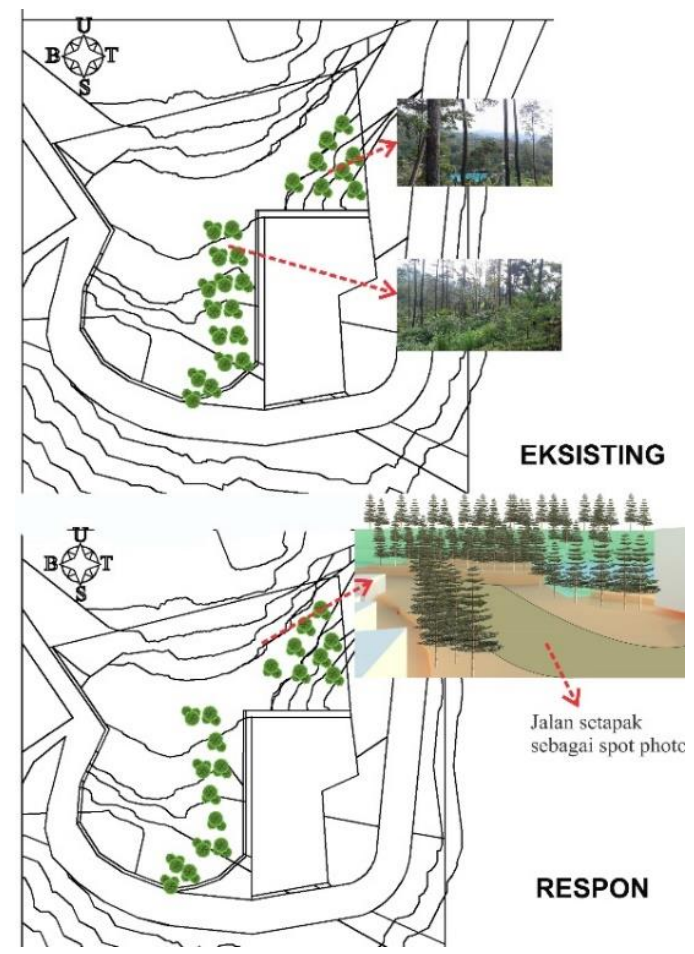

Gambar 11. Analisis Vegetasi Site
- Tanah

Kondisi tanah pada lokasi menurut hasil survey penulis dan data yang di dapat merupakan tanah yang mudah longsor maka dari itu untuk mengatasi kondisi tanah tersebut dengan tretment pemberian talud pada beberapa titik sebagai perkuatan dari tanah disana dan dengan metode soil nailing untuk perkuatan bangunannya.

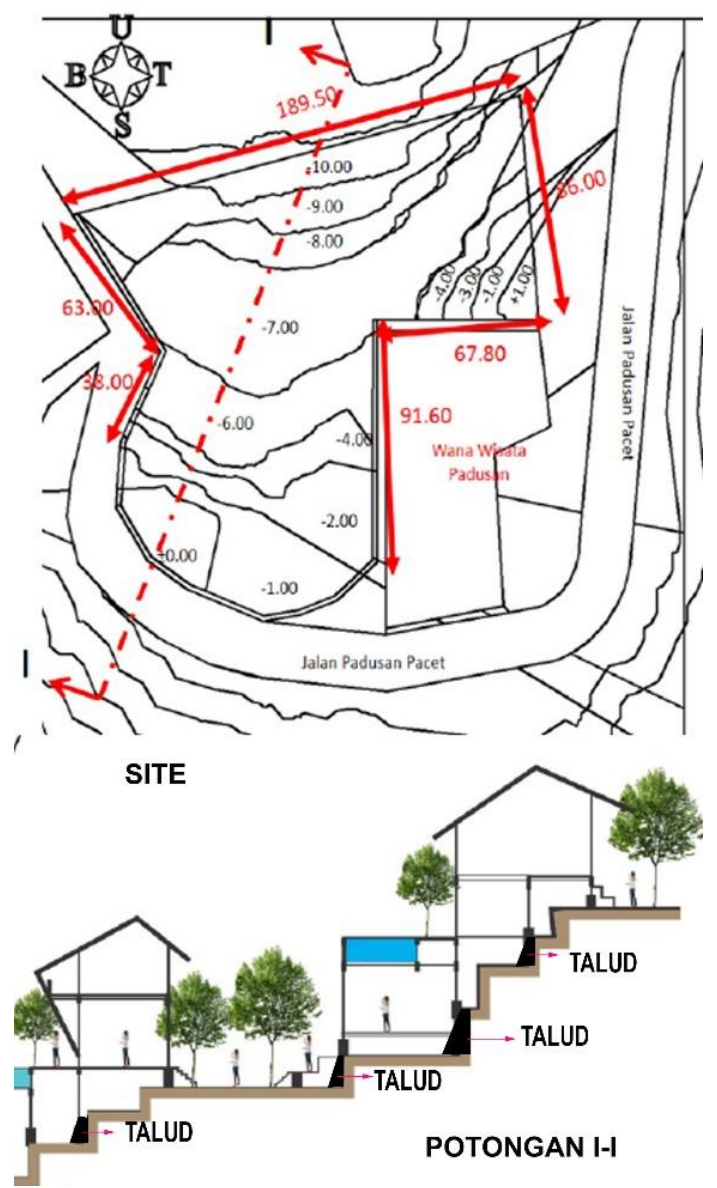

Gambar 12. Analisis Topografi

- Sumber Air Panas

Pemanfaatan sumber air panas yang ada di Padusan Pacet nantinya akan dimanfaatkan sebagai pendukung fasilitas yang terdapat pada Hotel Resort, seperti pemberian kolam berendam air panas pada setiap unit Resort dan fasilitas SPA pada Hotel Resort. 


\subsection{Perhitungan Kebutuhan Ruang}

\section{Asumsi Jumlah kamar Hotel Resort}

Kawasan Wana Wisata Padusan Pacet mengalami peningkatan sejak tahun 2015 sekitar 30\%-70\% dengan total 214540 pengunjung. Dengan total jumlah pengunjung tersebut didapat rata-rata pengunjung yang datang berrkelompok, keluarga atau berpasangan. Dari data tersebut di asumsikan bahwa rata-rata pengunjung yang menginap di Hotel Resort merupakan pengunjung yang berkelompok, berpasangan, dan berkeluarga.

Tabel 1. Jumlah wisatawan yang menginap di Padusan

\begin{tabular}{cc}
\hline Tahun & $\begin{array}{c}\text { Jumlah Wisatawan Yang } \\
\text { Menginap di Padusan }\end{array}$ \\
\hline $\mathbf{2 0 1 3}$ & 77.894 \\
\hline $\mathbf{2 0 1 4}$ & 83.512 \\
\hline $\mathbf{2 0 1 5}$ & 105.915 \\
\hline
\end{tabular}

Sumber : Dinas Pemuda, Olahraga, Kebudayaan dan Pariwisata, Kab Mojokerto, 2015(STATISTIK and MOJOKERTO 2016)

Rumus Proyeksi laju pertumbuhan menurut Nursiamidewi, W. 2017(Nursiamidewi 2017):

Keterangan:

$$
\boldsymbol{P}_{m}=\boldsymbol{P}_{o}+\frac{m}{n}\left(\boldsymbol{P}_{n}-P_{o}\right)
$$

$P_{m}=$ Jumlah Pada Tahun $m$

$P_{o}=$ Jumlah Pada Tahun dasar

$P_{n}=$ Jumlah Pada Tahun akhir

$m=$ Selisih Tahun $m$ dengan Tahun Dasar

$\mathrm{n}=$ selisih data pada tahun akhir dan tahun dasar

Dari rumus data dan rumus di atas diketahui :

$P_{2018}=$ Jumlah Pada Tahun 2018

$P_{2013}=77.894$

$P_{2015}=105.915$

$m=2018-2013=5$ tahun

$n=2015-2013=2$ tahun

$P_{2018}=77.894+\frac{5}{2}(105.915-77.894)$

$P_{2018}=77.894+2.5(28.021)$

$P_{2018}=147.946$

Jadi proyeksi peningkatan wisatawan yang menginap pada tahun 2018 mencapai 147.956 wisatawan. Presentase peningkata dari tahun 2013-2015 mencapai 30\% maka pada tahun 2018 jumlah wisatawan yang menginap sekitar 44.383 wisatawan. Asumsi rata rata wisatawan menginap sekitar 2 hari.

Rata-rata wisatawan menginap $=360$ hari : 2 hari $=180$ hari
Sehingga kebutuhan kamar setiap tahunnya :

$P_{2018}=\frac{44.383}{180}=247 \mathrm{kamar} /$ tahun

Perkiraan jumlah kamar di atas akan diselisihkan dengan jumlah akomodasi penginapan di wilayah padusan sesuai data survey yang di dapat yaitu 169 unit kamar dari semua penginapan yang ada di Padusan.

Sehingga kebutuhan Hotel Resort yang dibutuhkan $=247-169=\underline{78 \text { unit kamar }}$

Dari perhitungan jumlah kamar yang di butuhkan didapat hasil 78 unit kamar yang nantinya akan di bagi sesuai dengan type unit kamar Hotel Resort. Asumsi pembagian kamar di antaranya sebagai berikut.

Tabel 2. Besaran Ruang Type Penginapan Hotel Resort

\begin{tabular}{ccccc}
\hline $\begin{array}{c}\text { Type unit } \\
\text { penginapan }\end{array}$ & $\begin{array}{c}\text { kapas } \\
\text { itas }\end{array}$ & $\begin{array}{c}\text { Luas } \\
\left(\mathbf{m}^{2}\right)\end{array}$ & $\begin{array}{c}\text { Jum } \\
\text { lah }\end{array}$ & $\begin{array}{c}\text { Luas } \\
\text { total }\end{array}$ \\
\hline $\begin{array}{c}\text { Superior Room } \\
\text { (double bed) }\end{array}$ & 2 & $24 \mathrm{~m}^{2}$ & 16 & $\begin{array}{c}384 \\
\mathrm{~m}^{2}\end{array}$ \\
$\begin{array}{c}\text { Superior Room } \\
\text { (twin bed) }\end{array}$ & 2 & $24 \mathrm{~m}^{2}$ & 16 & $\begin{array}{c}384 \\
\mathrm{~m}^{2}\end{array}$ \\
Suite room & 4 & $48 \mathrm{~m}^{2}$ & 12 & $\begin{array}{c}576 \\
\mathrm{~m}^{2}\end{array}$ \\
$\begin{array}{c}\text { Family Pool } \\
\text { villa }\end{array}$ & 4 & 100 & 10 & $\begin{array}{c}1000 \\
\mathrm{~m}^{2}\end{array}$ \\
$\begin{array}{c}\text { Luxury Pool } \\
\text { Villa }\end{array}$ & 3 & $80 \mathrm{~m}^{2}$ & 12 & $\begin{array}{c}960 \\
\mathrm{~m}^{2}\end{array}$ \\
$\begin{array}{c}\text { Royal Pool } \\
\text { Villa }\end{array}$ & 2 & $60 \mathrm{~m}^{2}$ & 12 & $\begin{array}{c}720 \\
\mathrm{~m}^{2}\end{array}$ \\
$\begin{array}{l}\text { Total Keseluruhan kebutuhan luas } \\
\text { penginapan }\end{array}$ & & $\begin{array}{c}3124 \\
\mathrm{~m}^{2}\end{array}$ \\
\hline
\end{tabular}

Dari asumsi luas dasar bangunan yang di pakai sekitar $10.901 \mathrm{~m}^{2}$ sehingga di dapat perhitungan seperti berikut :

Total luas lantai dasar bangunan $=10.901 \mathrm{~m}^{2}+$ $30 \%$ sirkulasi $=\underline{14.171,3 \mathrm{~m}^{2}}$

KDB $=80 \%$ dari luas lahan 21.000 $\mathrm{m}^{2}=\underline{16.800 \mathrm{~m}^{2}}$

$\mathrm{KLB}=6 \times 21.000 \mathrm{~m}^{2}=\underline{126.000}$

Jumlah lantai $=126.000 \mathrm{~m}^{2}: 16.800 \mathrm{~m}^{2}$

$=7,5$ lantai (dibulatkan

menjadi 7 lantai) 
Dari perhitungan di atas dapat dilihat bahwa total luas lantai dasar bangunan memenuhi syarat KDB yang ditentukan pemerintah dimana KDB pemerintah $80 \%$ dari luas lahan dan bangunan Hotel Resort yang akan di desain nantinya hanya membutuhkan lahan sekitar $14.171,3 \mathrm{~m}^{2}$. dengan luas tersebut site memiliki sisa lahan sekitar $6.828,7 \mathrm{~m}^{2}$ yang akan dimanfaatkan sebagai taman pada site.

\section{KESIMPULAN}

\subsection{Zonasi}

Pada konsep Zonasi pada site penataan di atur sesuai dengan penataan masa pada keraton majapahit zaman dahulu. Menurut Raffles, 1981 " penataan masa ditata menurut zona private, semi private, dan public penataan tersebut ditata dari sisi utara ke selatan dimana sisi utara merupakan zona Private (Nista Mandala), Tengah merupakan Semi private (Widya Mandala) dan sisi selatan merupan zona Publik (Utama Mandala). Penataan tersebut akan di aplikasikan ke penataan Hotel Resort untuk menanggapi salah satu prinsip ekowisata yang telah dipilih yaitu Cultural Respect penataan zonasi tersebut akan di implementasikan pada Hotel Resort.

- Nista Mandala (Wilayah Utara)

Pada bagian utara pada site merupakan wilayah Nista Mandala yang merupakan area private pada tata masa keraton Majapahit yang di implementasikan pada site sebagai area penginapan Hotel Resort supaya tingkat privasi pengunjung yang menginap tidak terganggu dengan pengunjung yang hanya menikmati wisata alam yang ada di Padusan.

- Widya Mandala (Wilayah Tengah)

Pada bagian tengah pada site merupakan wilayah Widya Mandala yang merupakan area semi private pada tata masa keraton Majapahit yang di implementasikan pada site sebagai area fasilitas Hotel Resort seperti Café, Lounge, Spa dll supaya pengunjung yang hanya menikmati fasilitas Hotel Resort dapat masuk kedalam Hotel Resort tanpa mengganggu Privasi Pengunjung yang menginap selain itu peletakan fasilitas pada tengah site juga memudahkan akses pengunjung yang menginap menuju fasilitas yang sudah di sediakan.

- Utama Mandala (Wilayah Selatan)

Pada bagian selatan pada site merupakan wilayah Utama Mandala yang merupakan area publik pada tata masa keraton Majapahit yang di implementasikan pada site sebagai area parkir, Main Gate, Lobby, souvenir shop, dll untuk memudahkan akses masuk pengunjung dan pengelola pada Hotel Resort
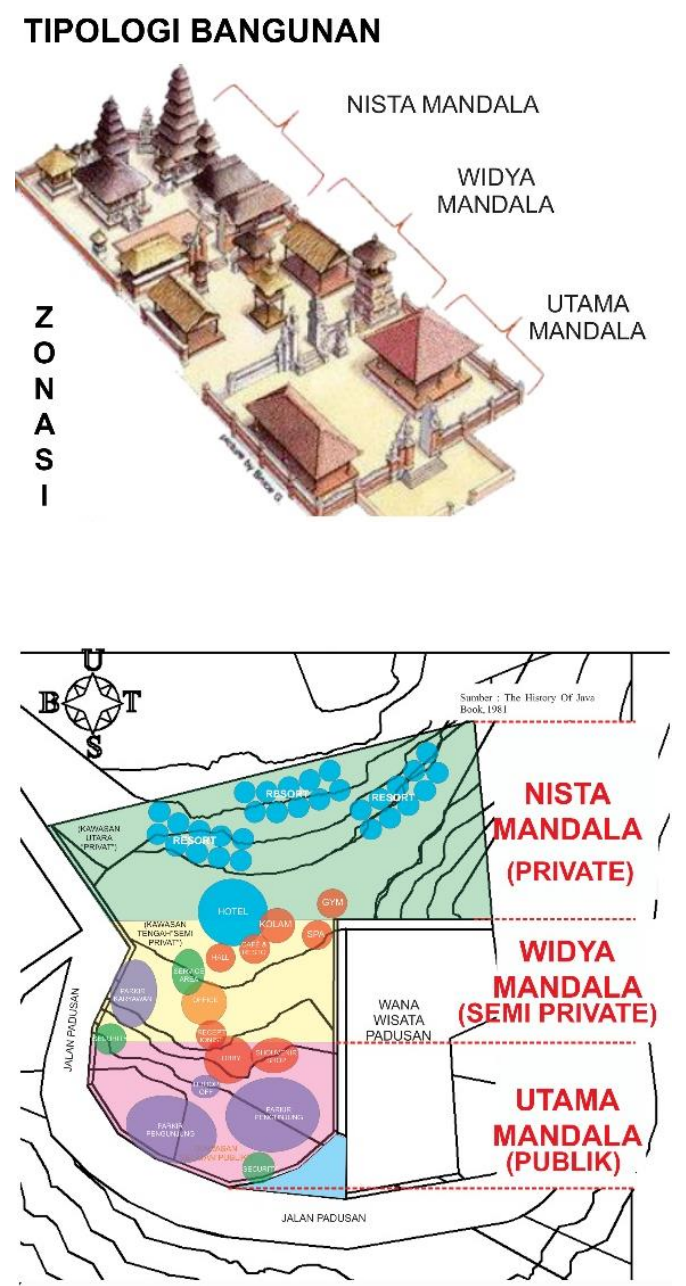

Gambar 13. Penerapan Zonasi Majapahit Pada Site

\subsection{Gubahan dan Tata Masa}

Konsep penataan tata masa pada Hotel Resort mengikuti pola kontur tanah dengan cara dipisah antara masa penginapan dan masa fasilitas dengan diberi penghubung sirkulasi berupa ramp dan jalan setapak yang diberi pergola sebagai naungan guna menambah kenyamanan pengunjung ketika berjalan, 
Pemisahan masa di atur sesuai dengan konsep zoning yang mengikuti pola dari penataan keraton Majapahit yang ditata sesuai dengan zona public sampai privat yang ditata dari utara ke selatan. Penataan tersebut merupakan penerapan dari konsep ekowisata Natural Area Focus dan Cultural Respect dimana penataan masa mengikuti pola kontur dan dan penataan fungsi masa mengikuti pola penataan masa yang ada di keratin majapahit untuk menanggapi cultural respect pada konsep ekowisata. Penataan masa juga menyikapi potensi view di kawasan Padusan dimana potensi view paling banyak berada disisi utara karena terdapat view perbukitan dan terasering persawahan maka dari itu penataan masa penginapan diletakkan disisi utara supaya pengunjung yang menginap di Hotel Resort mendapatkan view pemandangan alam Padusan.

\section{TATA MASA}

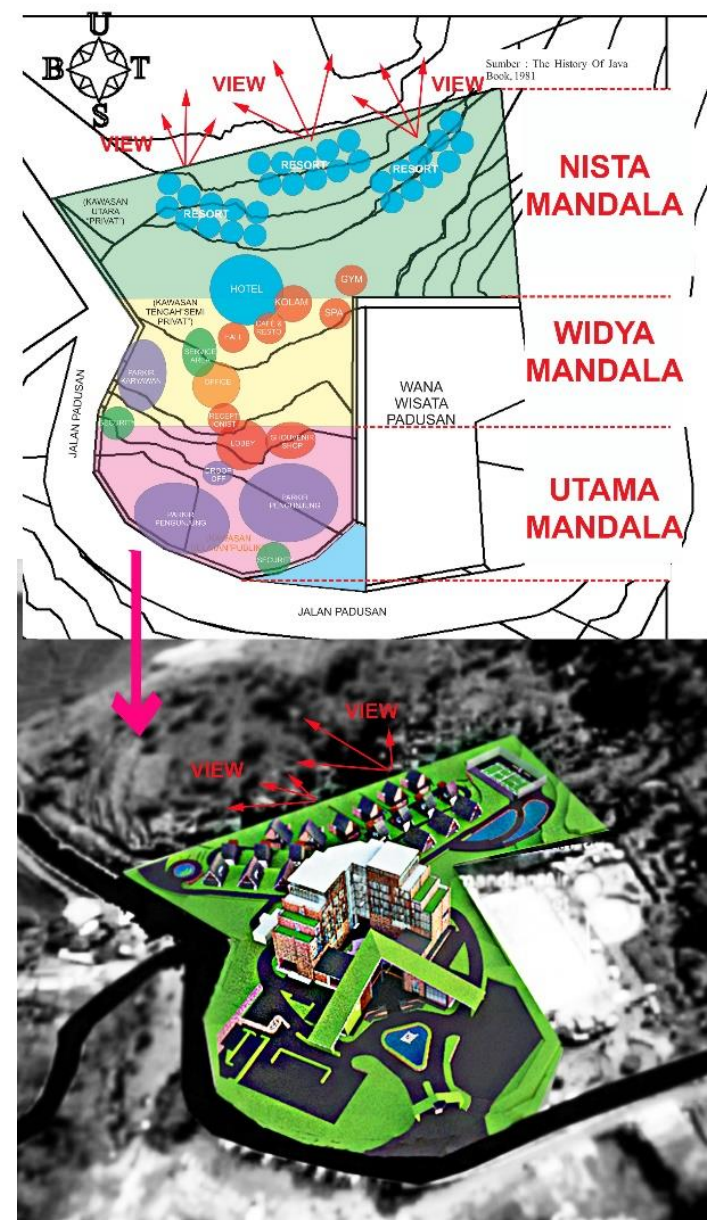

Gambar 14. Penataan Masa
Bentuk masa bangunan Hotel merupakan hasil transformasi dari bentuk atap bangunan rumah lokal dan bentuk gerbang Majapahit yang merupakan ciri khas dari bangunan lokal di sekitar Pacet. Dimana ciri bentuk gerbang majapahit apabila di lihat berupa Solid-VoidSolid nantinya akan di aplikasikan pada bentuk Hotel supaya dapat menjadi ciri khas bangunan Hotel Resort di Pacet. Untuk bagian solid si sisi kanan dan kirinya menggunakan material bata ekspose dan juga kisi-kisi kayu supaya bangunan pada sisi kanan dan kirinya terlihat solid. Pada void yang berada di bagian tengah bangunan nantinya akan mengaplikasikan material kaca supaya pada sisi tengah membentuk siluet void pada bangunan.

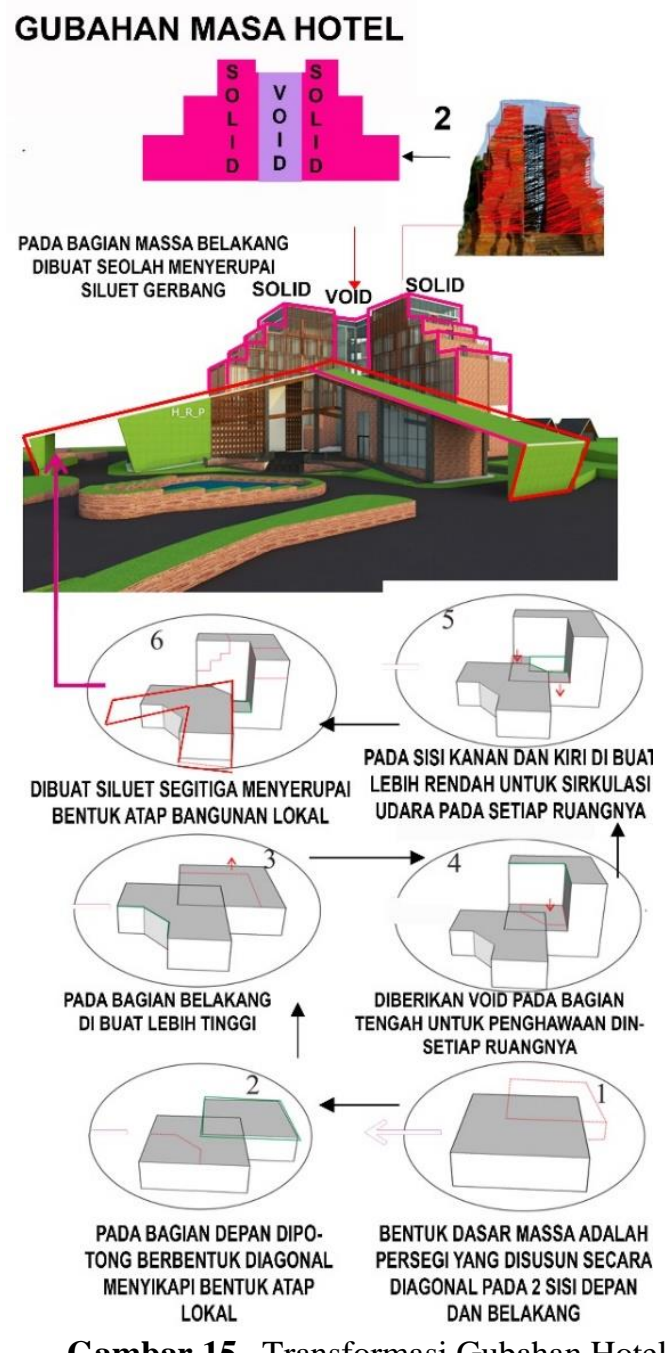

Gambar 15. Transformasi Gubahan Hotel

Main gate merupakan akses penanda masuk ke lokasi site. Pada bentuk main gate nantinya akan dibuat dari transformasi bentuk atap segitiga bangunan lokal yang di buat lebih 
atraktif dan unity dengan bentuk Hotel Resort yang juga terdapat garis segitiga di bagian depan. Dan siluetnya juga jadi lebih terlihat dari depan site sampai belakang site.

\section{GUBAHAN MASSA MAIN GATE}

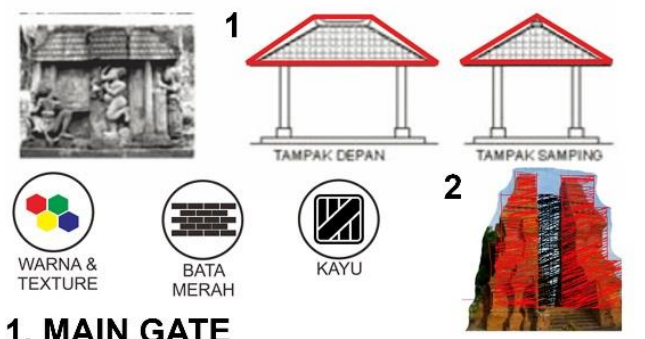

\section{MAIN GATE}

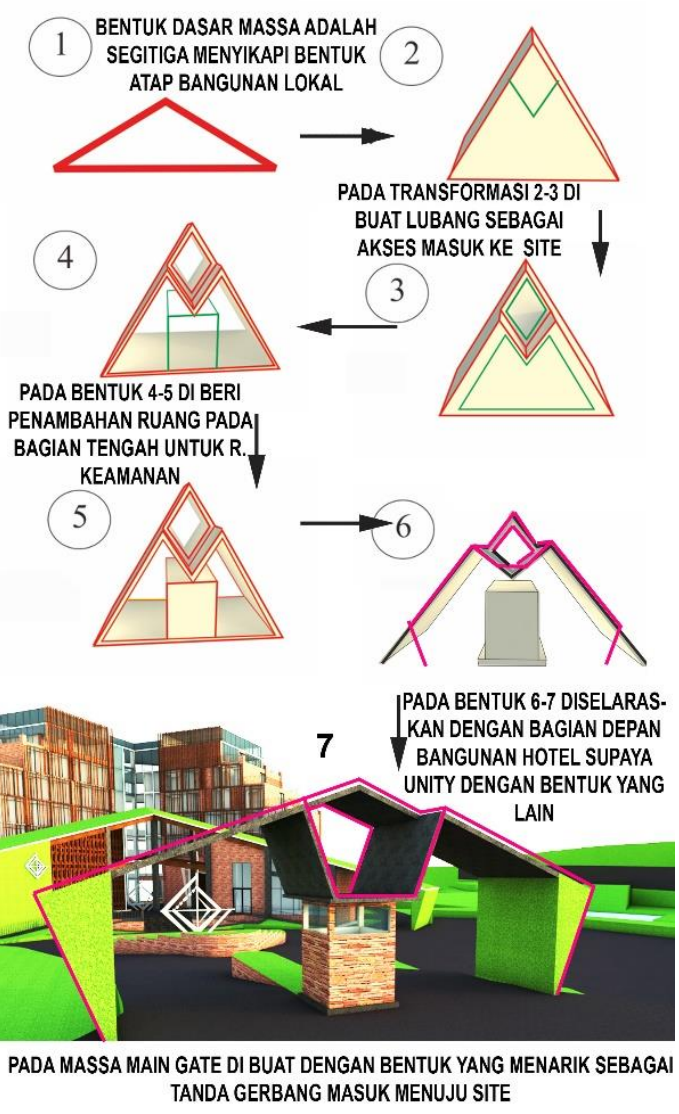

Gambar 16. Transformasi Gubahan MainGate

Pada masa Resort merupakan transformasi dari bentuk atap bangunan lokal yang berupa segitiga yang akan di selaraskan dengan bentuk main gate dan hotel supaya terlihat unity dengan masa yang lain. Dengan memberikan bukaan yang lebar pada sisi utara untuk menyikapi potensi view yang ada pada site. Memberikan beberapa kisi-kisi yang terbuat dari kayu untuk memaksimalkan penghawaan pada ruangan Resort yang di desain. Selain dengan adanya kisi-kisi yang terbuat dari kayu pengaplikasian material ekspose seperti batubata dan semprot semen juga akan memberikan kesan natural pada bangunan Resort.

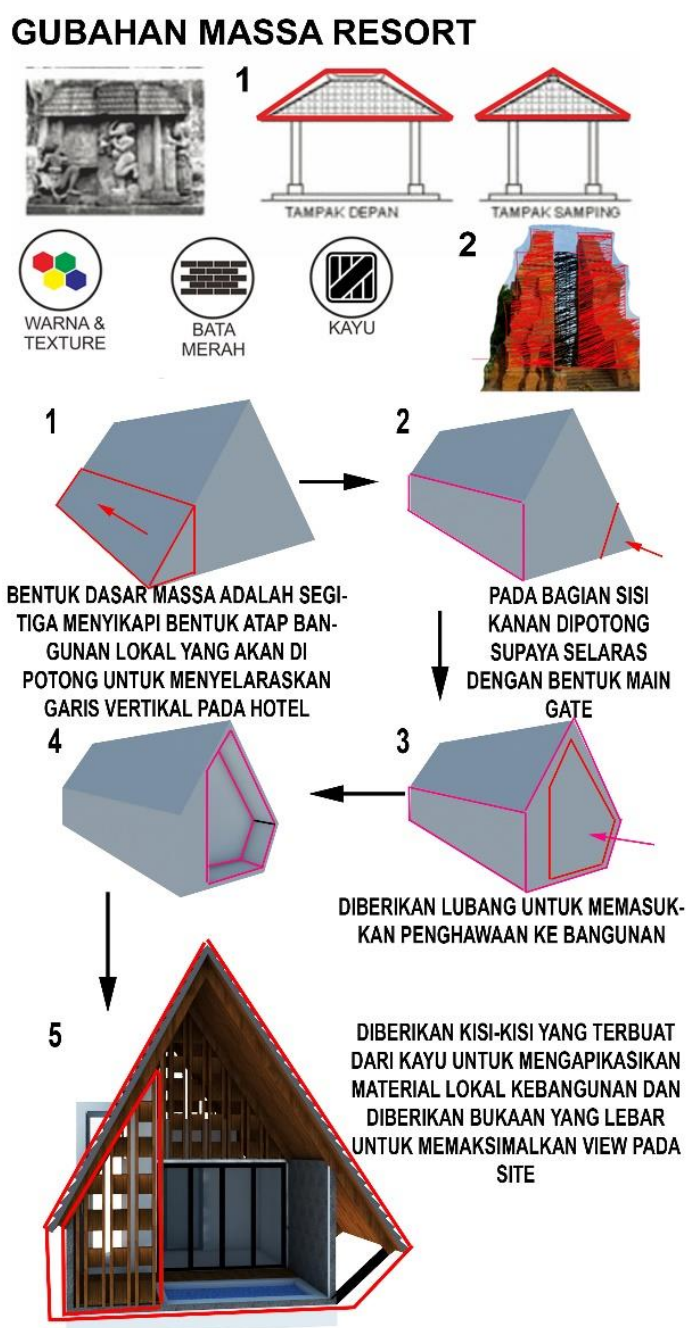

Gambar 17. Transformasi Gubahan Resort

\subsection{Struktur Material}

Sistem struktur pada bangunan hotel dibuat dengan modul kolom 80/80 dalam bentang $8 \mathrm{~m}$. Penataan modul penginapan hotel $2 \mathrm{kamar}$ dalam 1 modul. Pada atap hotel memakai atap dak beton pada sisi kanan dan kiri dan pada bagian tengah memakai atap skylight. Menggunakan panoramic lift untuk akses menuju tiap lantainya dan tangga darurat untuk akses pengunjung apabila terjadi bencana kebakaran. Pada sisi depan Hotel menggunakan roof garden dengan penutup rumput yang dilapisi dengan dak beton. Untuk struktur bagian bawah menggunakan pondasi borpile 
dengan perkuatan talud setiap sisinya untuk memperkuat daya dukung tanah.
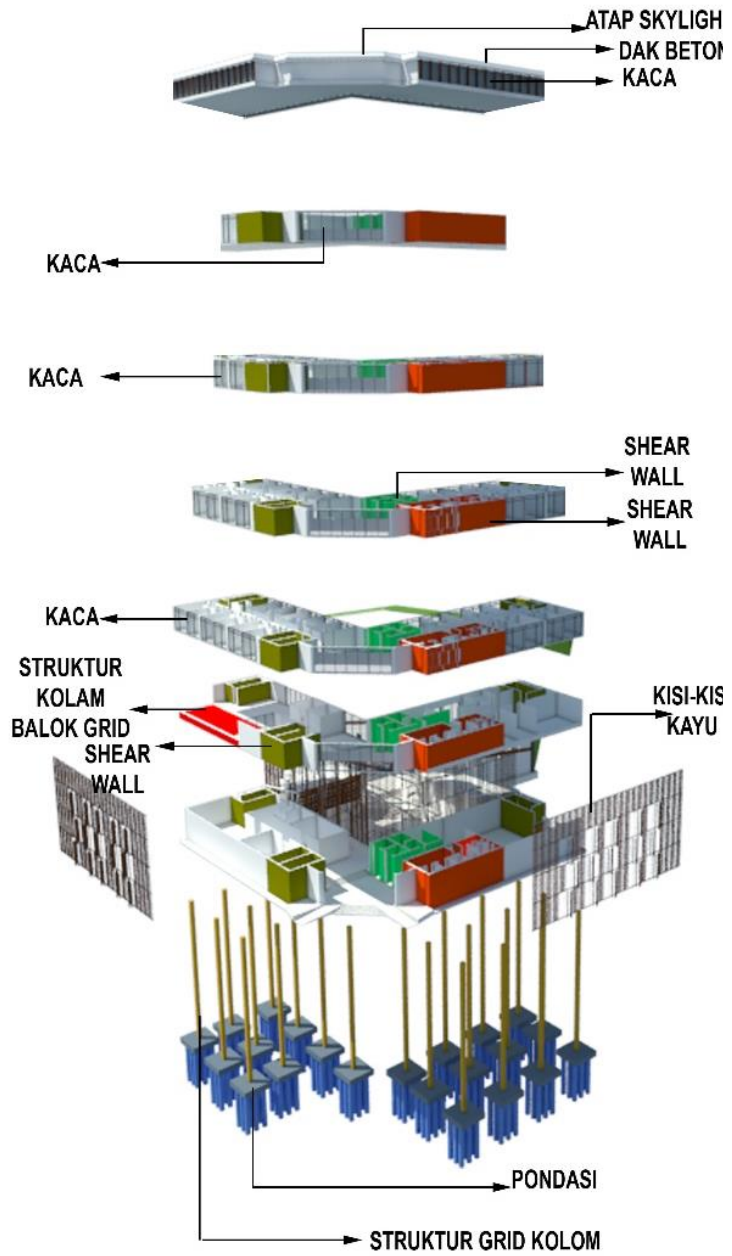

Gambar 18. Eksplodametri Struktur Hotel

\subsection{Hasil Desain}

Penerapan konsep ekowisata pada Hotel Resort di aplikasikan pada bentuk dan tata masa bangunan yang menyesuaikan 3 prinsip Ekowisata yang bisa di aplikasikan pada Hotel Resort yang ada di Pacet, yaitu Natural Area Focus, Contribution To Conservation, dan Cultural Respect. Berikut merupakan hasil desain yang di buat menyesuaikan 3 prinsip ekowisata.

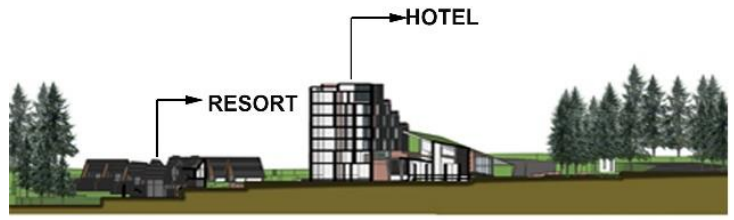

Gambar 19. Potongan Kawasan Hotel Resort

Pada kondisi tanah pada Site yang berkontur untuk menyikapi prinsip Contribution To Conservation penataan masa mengikuti kondisi Kontur Tanah eksisting untuk mengurangi cut and fill pada tanah dengan perkuatan talud di beberapa titik pada Site.

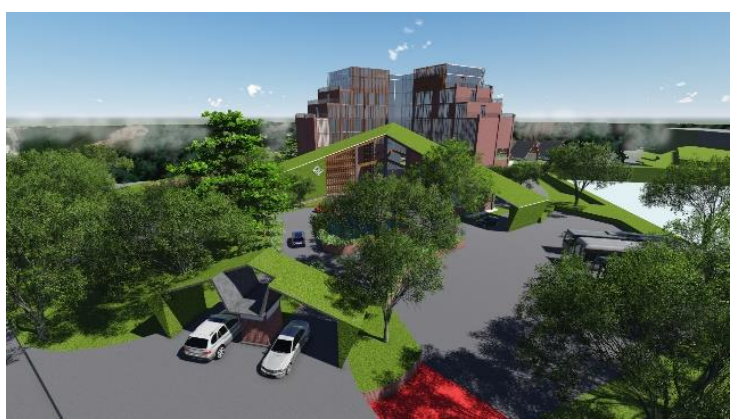

Gambar 20. Perspektif Hotel Resort

Pada penataan landscape pada Site sesuai dengan prinsip Natural Area Focus memanfaatkan tanaman eksisting yang ada di dalam Site supaya ekosistem yang ada tidak rusak. Selain itu pada beberapa area diberikan tanaman tambahan untuk memperkuat kesan sejuk pada area Hotel Resort.

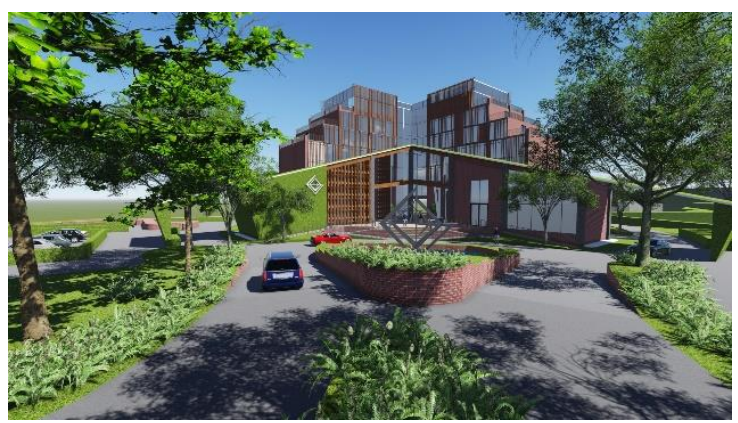

Gambar 21. Perspektif Bentuk Kawasan Hotel Resort

Pada bentuk masa Hotel Resort untuk menyikapi prinsip Cultural Respect, bentuk masa didesain dari transformasi gabungan bentuk gerbang candi dan bentuk atap bangunan rumah jawa yang segitiga, selain itu gerbang candi sendiri di ambil dari siluetnya 
yang merupakan Solid-Void-Solid. Untuk materialnya dipilih material lokal berupa batu bata ekspose sebagai pembentuk warna pada fasad bangunan.

\section{UCAPAN TERIMAKASIH}

Terimakasih kepada teman-teman satu angkatan Tugas Akhir dan para dosen di Prodi Arsitektur UTY yang telah membantu dalam perkembangan proses mendesain sampai penulisan jurnal ini.

\section{REFERENSI}

Fifi Ambarwati, Agung Kumoro W., Leny Pramesti. 2012. "HOTEL RESORT DENGAN PENDEKATAN ARSITEKTUR EKOLOGIS DI BATU MALANG." Arsitektura 10: 76-83. https://jurnal.uns.ac.id/Arsitektura/articl e/view/11396/10166.

Kampung, D I et al. 2019. "STRATEGI PENGEMBANGAN EKO-WISATA BERBASIS MASYARAKAT Kota Yogyakarta Yang Merupakan Salah Mempunyai Potensi Wisata Yang Daya Tarik Wisata Yang Saat Ini Adalah Desa Wisata Didefinisikan Sebagai Desa Yang Memiliki Potensi Keunikan Dan Daya Tarik Wisata Kehi." XV(1): 1-11.

Marlina, Endy. 2008. "Klasifikasi Hotel \& Resort."

Mojokerto, Bapedda Kabupaten. Rencana Tata Ruang Wilayah Kabupaten Mojokerto Tahun 2012-2032.

NEGERI, MENTERI DALAM. 2009. PERATURAN MENTERI DALAM NEGERI NOMOR 33 TAHUN 2009 Tentang PEDOMAN PENGEMBANGAN EKOWISATA DI DAERAH.

Nursiamidewi, W. 2017. "Hotel Resort Bintang 3 Di Indramayu." Universitas Diponegoro.

Resort, Konsep, and Yang Berkelanjutan. 2014. "Darsiharjo Dan Ghoitsa Rohmah Nurazizah: Konsep Resort Yang Berkelanjutan ( Kasus Resort Di Indonesia ) ( RESORT CASE IN INDONESIA ) Jurnal Manajemen Resort \& Leisure." Jurnal Manajemen Resort \& Leisure 11 no.2.

Shukri, Mohd, and Ab Yajid. 2015. "Eco-
Tourism Practices in Sri Lankan Eco Resorts : An Analysis of Satisfaction and Behavioral Intention of Eco-Tourists." 6(10): 211-26.

Society, The International Ecotourism. 2015. "What Is Ecotourism?" https://ecotourism.org/what-isecotourism/.

STATISTIK, BADAN PUSAT, and KABUPATEN MOJOKERTO. 2016. Statistik Daerah Kecamatan Pacet. Mojokerto. 